UDC: 347

DOI https://doi.org/10.24144/2307-3322.2021.63.34

\title{
REGARDING THE SUBJECT OF THE CONTRACT FOR THE SUPPLY OF MATERIAL RESOURCES TO MILITARY UNITS (LEGAL ENTITIES UNDER PUBLIC LAW)
}

\author{
Pavlovskyi O., \\ postgraduate student of the Department of Civil Law № 2 \\ Yaroslav Mydryi National Law University
}

\section{Pavlovskyi O., Regarding the subject of the contract for the supply of material resources to military units (legal entities under public law)}

In accordance with Part 2 of Art. 17 of the Constitution of Ukraine, military units, first of all, are the bearers of power and act in public relations as subjects of realization of the goal set by the state in the form of repulse of possible aggression from outside, and therefore the main tasks, internal structure, subordination, reporting and control in this area is governed by constitutional and administrative law. However, in some cases, the military unit for the implementation of its tasks may act as an independent entity in civil law, and therefore, certain relations are governed not only by constitutional, administrative, economic, but also civil law. This paper will deal with contractual obligations.

The supply contract is extremely important in providing Ukraine, its subjects and state entities with the necessary goods, performance of works, provision of services. In essence, the institute of contract law is a legal means of implementing state policy in the field of industrial production, construction, national defense, social assistance, science, culture, the implementation of basic social and production tasks. Currently, there is a trend aimed at increasing the budget funds used through public procurement.

In this regard, an urgent problem is the effective legal regulation of public relations related to the supply of goods for public use. The regulatory framework governing these legal relations must be transparent, understandable to all participants in trade and procurement operations, operational on changes in socio-economic conditions in the country, have an anti-corruption orientation. The quality of goods purchased for the state also remains a long-standing problem.

One of the topical issues for the science of civil law is the question of the subject of the contract, with which the Central Committee of Ukraine connects the conclusion of the contract, its validity and some other significant circumstances. According to case law, disputes arising from the contract are usually complicated by non-compliance by the parties with the provisions of the Civil Code of Ukraine on the subject of the contract.

The article analyzes the subject of the contract for the supply of material resources to military units. Military units are considered by the author as legal entities of a subject of public law.

Key words: military units, supply contract, purchase and sale, subject, object, legal relations, parties, conditions, quantity, quality, completeness.

\section{Introduction.}

With the introduction of market relations in our country, civil law agreements have become especially noticeable, giving rise to relations between individuals, both individuals and legal entities. The contract defines the elements of civil relations, such as: the subjects of the contract, subjects and objects of the contract, the content of the contract, consisting of the rights and obligations of the parties. This increases the role of civil law in modern economic conditions.

The contract is one of the oldest legal constructions. Earlier, only torts arose in the history of contract law for a contract. Being by its nature a negative reaction on the part of the state to deviations from the established criteria of proper conduct, torts were the direct successor of one of the most disgusting remnants of the tribal system revenge [1].

The main requirement at the present stage, which the legislator puts forward in order for a civil contract to be considered concluded, is the agreement of all essential conditions by the parties; to the essential conditions of the contract the legislator refers to the condition of its subject (Part 1 of Article 638 of the Civil Code of Ukraine). However, there is no legal definition of this legal category in the legislation, which creates a number of differences in the understanding of the subject of the contract both in the doctrine of law and in law enforcement practice. 
It should be noted that the doctrine does not have a single approach to the definition of «object of rights», «object of the contract», «subject of the contract», the analysis of which will focus.

The object of civil rights is a category of objective law. Article 177 of the Civil Code of Ukraine contains a list of objects of the following rights: things, including money and securities, other property, property rights, results of works, services, results of intellectual creativity, information, as well as other tangible and intangible benefits. These are benefits for which the parties may enter into various agreements between themselves. In this case, it is possible to use such a concept as «object of the contract». For example, the parties have entered into a lease (lease) of a vehicle, in which case we can speak of the object of the lease as the object of rights and the subject of the lease as an essential condition. Thus, the object of civil law is a category of objective and subjective law.

The object of the contract - goods and other property, the result of work, service and its result, if it is objectively possible. The object of the contract is a narrower concept than the subject of the contract. This is one of the benefits for which the parties enter into a legal relationship with each other.

The tradition of determining the subject of the contract was initiated by K. Kavelin, who considered necessary under this agreement actions that lead to the desired result for the parties. The subject of the contract is the main essential condition. The subject, as a rule, covers the object of the contract and the set of actions (abstention) of the parties in relation to the object and to each other. Thus, in the supply contract the object is the goods, and the subject - the actions of the supplier and the actions of the buyer or their rights and obligations: the supplier is obliged to transfer the goods in due time, and the buyer is obliged to accept the goods and pay its value [2, p. 113]. According to S. Shimon, the subject of the contract should serve as a means (criterion) of distinguishing a certain type of contract within a certain type of contract [3, p. 62].

The subject of the contract includes both the presence of the object of the contract and a set of actions (abstentions) of the parties in relation to this object and in relation to each other. The object of the contract is a good, and its subject is an action (refrain from actions), which is carried out by the parties in relation to this good. The object of the contract may be the benefits established by Art. 177 of the Civil Code of Ukraine. They must meet the requirements of the legal regime: turnover, divisibility, indivisibility, mobility, real estate, etc. The object and subject of the contract are objectively existing and related legal categories of contractual constructions. They must meet the requirements of civil law.

In accordance with Part 1 of Art. 712 of the Civil Code of Ukraine under the supply contract, the seller (supplier), which carries out business activities, undertakes to transfer the goods to the buyer for use in business activities or for other purposes not related to personal, family, home or other similar use, and the buyer agrees to accept the goods and pay for it a certain amount of money. According to E. Sukhanova, the contract is the most important means of legal regulation of property and related non-property relations [4, p. 40].

D. Dozhdev adds such an element as legitimacy - the power to dispose of the object of the transaction [5, p. 127]. Under it, the scientist pointed out that the subjects of contractual relations have a legally recognized basis for transactions on the disposal of the property in respect of which the agreement is concluded: «only that thing which is open to intrusion, specified in the transaction, may become the object of new rights and obligations in accordance with the will of such a person [5, p. 128]. It is not possible to conclude a contract of sale if the buyer and seller have not agreed on which items will be sold in accordance with this contract [6, p. 33].

Terms of the subject of the contract individualize the subject of performance (for example, the name and quantity of goods supplied), and often determine the nature of the contract. Thus, the condition of paid transfer of an individually-defined thing characterizes the contract of sale, and in its manufacture - the contract .... [7, p. 164].

Thus, there are two possible answers to the question of what is the subject of the contract: 1 ) the subject of the contract is a specific good for which it is concluded (ire the subject of the contract is synonymous with the concept of «object of civil law» (Article $177 \mathrm{CC}$ )) ); 2) the subject is the action of transfer (or creation and transfer) of this good from one subject to another (the subject of the contract is not synonymous with the term «object of civil law», but denotes the action of transferring the latter to an authorized person). According to V. Vitryansky, the subject of the contract of sale are the actions of the seller aimed at transferring the goods to the ownership of the buyer and, accordingly, the actions of the buyer accepting the goods and paying the price for it [8, p. 312].

V. Vitryanskyi also calls the conditions on the name and quantity of goods significant in relation to the purchase and sale of the Central Committee of Ukraine. Without their approval, the contract of sale is not considered concluded [8, p. 312].

According to O. Ioffe, the subject of the contract of sale must inevitably be embodied not in one, but in two material, legal and volitional objects. In this case, under the material objects in the contract of sale, the author understood that the property is sold and a sum of money is paid for it; under legal - the actions of the parties aimed at the transfer of property and payment of money; under volitional - the individual will of the seller and the buyer within the limits 
within which it is subject to the legislation governing their relations [9]. A similar point of view was expressed by M. Braginsky, believing that in the legal relations arising from the contract of sale, there are two kinds of objects: the object of the first kind are the actions of the obligated person, and the role of the object of the second kind is a thing that as a result of such an action must be transferred [10]. Thus, the subject of the contract of sale directly covers the goods (its name and quantity) and the relevant actions of the parties arising from the contract.

The stated scientific positions of M. Braginsky and O. Ioffe, undoubtedly, deserve respect as they reflect the known concept of structure of the contract according to which the subject is considered in a broad sense of the word, and covers all conditions concerning which the contract is concluded. The structure includes not only all information about the subject, including the quality, quantity and price of goods transferred, work performed and services provided, but also a set of actions that the parties must take to transfer or receive the goods.

However, we cannot fully agree with the meters of domestic civilization on this issue for such reasons. If you turn to Art. 691 of the Civil Code of Ukraine, in which the price is allocated as an independent condition of the contract, as well as take into account the requirement of quality (Article 673 of the Civil Code), quantity of goods (Article 669 of the Civil Code), as well as range (Article 671 of the Civil Code) . 682 CC), which are set before the sale (delivery), we can draw only one conclusion: without these conditions, the contract becomes «nothing.»

In contracts aimed at the transfer of property, the subject is what the contract is concluded, in our case - a product that is characterized by price, quality, quantity, range, completeness (raw materials, components, etc.).

In this regard, the actions taken to transfer the goods go beyond the conditions that characterize the subject of the supply contract.

In the supply contract, the subject is a product that is characterized by price, quantity, quality, range and completeness. And in the supply contract, in order to avoid the situation of its recognition as not concluded, it is necessary to indicate not only the groups of goods by name, but also their quantity. Of course, it is desirable to implement such an agreement by concluding a supply contract in writing with a detailed definition of all material conditions [11].

Under the supply contract, based on its subject, you can identify the purpose of delivery - to meet the needs of the buyer, not related to personal, family, home and other similar uses.

In this case, the purpose is not related to personal use, should be understood including the purchase of goods to ensure their activities as an organization or individual entrepreneur. Such goods, in particular, include office equipment, office furniture, vehicles, materials for repair work and more.

Under the supply contract, entities can establish long-term economic cooperation, which is stable. This is especially valued in the relationship between producers of goods and suppliers of raw materials or components, as well as between producers of goods and wholesale trade organizations that specialize in the sale of these goods.

An important distinguishing feature of the supply contract is the time difference between the conclusion of the contract and the transfer of goods, which should usually take place later. This feature is due to two reasons. First, the goods to be delivered at the time of the contract are often absent in kind, it must be manufactured or procured by the supplier in accordance with the buyer's order. Secondly, the supply contract serves the process of material or commodity supply to customers, which often requires systematic, repeated transfer of goods in separate batches over a long period. Based on this, the legal literature suggests that the main purpose of allocating a supply contract in a particular type of contract of sale should recognize the need for detailed legal regulation of relations between professional participants in property turnover ... These legal relations should be stable and have a long-term nature. Therefore, in the legal regulation of relations arising from the supply contract, the predominant importance is not one-time transactions for the transfer of goods, and long-term contractual relations between suppliers and buyers [8, p. 117].

Separation of the supply contract can be made based on the characteristics of the goods sold. Thus, under the contract of sale as an object can be absolutely anything not removed from civil circulation, which is determined not only by generic features, but also individually-defined. Thus under the contract of sale the thing is alienated on the property right to the buyer. On the contrary, under the supply contract the goods may be transferred to the other party both on the right of ownership and on another property right, if the participant of the transaction is a certain state body. For example, if the party to the supply contract is the Ministry of Defense of Ukraine (or its representative), the goods are purchased for a military unit, the military unit acquires a real right to this property. According to Yu. Romanets, the contract of supply of goods for state needs, firstly, is characterized by generic features of purchase and sale as a type of contract, secondly, has the properties of supply as a type of purchase and sale and, thirdly, has its distinctive qualities that necessitate the development of specific legal regulation [12, p. 282].

This agreement, like any other type of sale, is aimed at the paid transfer of property (transfer of property on another property right) in exchange for an equivalent-specific monetary provision. These generic features have de- 
termined the possibility of applying to this contract the general provisions of the sale, which does not contradict the specifics of the supply as such and the peculiarities of the supply for public needs.

Ordinary supply contracts (including with the participation of government agencies) are concluded between independent economic entities at their discretion. The supplier and the buyer are guided by the law of value and the purpose of profit. However, in today's economy there are certain state needs that must be met in order to maintain the normal existence and development of social relations. This includes, in particular, the creation of a state reserve, maintaining the required level of defense capabilities of the country, ensuring export supplies to meet international obligations, the implementation of state and regional target programs. Therefore, the state must plan the economic activities that are necessary to meet the above needs and ensure the implementation of its plans. Of particular importance for the state of a certain range of sales relations necessitates the creation of a legal mechanism that ensures the implementation of these tasks.

Conclusions. Thus, the qualifying feature of the contract for the supply of goods for state needs is the special significance of a certain group of contracts of sale for the state.

The main features of the legal regulation of this agreement are expressed in a special order of its conclusion and consideration of differences arising in its conclusion; guarantees to state customers of payments for delivered goods; the possibility of compensation for damages caused in connection with the performance or termination of the state contract; establishment of special cases of contract termination and a number of other legal mechanisms.

Results. The contract of supply by legal nature is a complex form, as it regulates commodity-money, property and organizational relations in the field of production.

The use of such a contractual form of production and sale of products and goods allows to refer the supply contract to a specialized legal institution of civil law, because these agreements regulate relations related to the production of both industrial and technical products and consumer goods.

The subject of the contract is not only the good itself (the object of civil law), but also the action that must be taken against it by one or both parties. In the supply contract, the subject is a product that is characterized by price, quantity, quality, range and completeness. Moreover, in the supply contract, in order to avoid the situation of its recognition as not concluded, it is necessary to indicate not only the groups of goods by name, but also their quantity.

The application to this agreement of the provisions governing the contract of sale is insufficient, and in some cases unacceptable. The contract of sale provides for the sale of goods that are the finished product of production, economic or other activities, and the object of delivery is a materialized result of the production or organizational process. That is why they need additional legislative consolidation of the provisions of the Central Committee of Ukraine on the settlement of the supply contract, supply contract for state needs, in particular, their subject, status of the parties, procedure, conditions of execution and liability for breach of contract.

\section{REFERENCE:}

1. Покровский И. А. (1918). История римского права. Петроград: Изд. Юрид. книжн. склада «Право», 430 с.

2. Кавелин К. Д. (1879). Права и обязанности по имуществам и обязательствам в применении к русскому законодательству. Опыт систематического обозрения. СПб. : Тип М. М. Стасюлевича, 459 с.

3. Шимон С. (2011). Об'єкт і предмет договору і цивільного правовідношення: нотатки для наукової дискусії. Юридична Україна. № 4. С. 58-64.

4. Гражданское право: учеб. В 2 т. Т. 2 (2002). / Под ред. Е. А. Суханова. М.: БЕК, Полутом 1. 704 с.

5. Дождев Д. В. (1997). Римское частное право: учебн. /Под ред. В. С. Нерсесянца. М.: НОРМА-ИНФРА-М, 784 с.

6. Корецкий А. Д. (2004). Договорное право России. Основы теории и практика реализации. М.: ИКЦ «МарТ», Ростов н/Д: Изд. Центр «МарТ», 528 с.

7. Гражданское право: учеб. В 2 т. Т. 1 (2003). / Под ред. Е. А. Суханова. М.: БЕК, 816 с.

8. Витрянский В. В. (1999). Договор купли-продажи и его отдельные виды. М.: Статут, 284 с.

9. Иоффе О.С. (1975). Обязательственное право: учебн. М.: Юрид. лит-ра, 880 с.

10. Брагинский М.И., Витрянский В.В. (1997). Договорное право: Общие положения. М.: Статут, 848 с.

11. Казакова Е. Б. (2019). Договор поставки - основные проблемы его применения. Наука. Общество.

Государство. Т. 7. № 1(25). URL: http://esj.pnzgu.ru.

12. Романец Ю. В. (2006). Системы договоров в гражданском праве России. М.: Юристъ, 496 с. 